Research Article

\title{
COMPARATIVE EFFICACY OF SILVER METALLIC PLASTIC MULCH, BOTANICALS AND INSECTICIDES IN CONTROLLING TOMATO YELLOW LEAF CURL DISEASE
}

\author{
S. Akter, M.B. Hossain ", S. Akter, T. Hasan and A.U. Mahmud \\ Department of Plant Pathology \\ Sher-e-Bangla Agricultural University \\ Sher-e-Bangla Nagar, Dhaka, Bangladesh
}

\begin{abstract}
Tomato Yellow Leaf Curl caused by Tomato Yellow Leaf Curl Virus (TYLCV) is one of the most important diseases of tomato causing heavy losses in yield and quality of fruits. Damage caused through phloem feeding and transmission of TYLCV by the insect vectors whitefly (Bemisiatabaci). In this study the competence of silver metallic plastic mulch, botanicals and insecticides were assessed to manage the Tomato Yellow Leaf Curl Virus (TYLCV) by controlling the insect vectors. In total 7 treatments including control were considered viz. $\mathrm{T}_{1}=$ Imidacloprid, $\mathrm{T}_{2}=\mathrm{ACmix}, \mathrm{T}_{3}=$ Subicron, $\mathrm{T}_{4}=$ Neemax, $T_{5}=$ Multineem, $T_{6}=$ Silver metallic plastic mulch and $T_{7}=$ Control. All the treatments showed significant influence on different assayed parameters in the test crop tomato. The lowest disease incidence, disease severity and whitefly association was found in $\mathrm{T}_{6}$ treatment (silver metallic plastic mulch) that was $2.87 \%, 1.72 \%$ and $2.0 \%$ at 60 days after transplanting (DAT) respectively. While the highest disease incidence, disease severity and whitefly association were found in $T_{7}$ treatment (control treatment) that was $14.71 \%$, $46.22 \%$ and 18, respectively, at 60 DAT. From the relationship study between disease incidence and disease severity with whitefly association, it was revealed that disease incidence and severity of TYLCV was increased with increasing of whitefly population and vice-versa. Among the treatments, growth parameters, yield and yield attributers were also found better in $\mathrm{T}_{6}$ treatment (silver metallic plastic mulch). Silver metallic plastic mulch is the best option to manage the TYLCV by controlling the insect vectors, whitefly instead of insecticides.
\end{abstract}

Keywords: Tomato, TYLCV, Whitefly, Botanicals, Silver metallic plastic mulch

*Corresponding author: dr.mbhossain@ sau.edu.bd 


\section{INTRODUCTION}

Tomato (Solanum lycopersicum L.) is one of the most popular and nutritious vegetable all over the world including Bangladesh. But the yield of the tomato in Bangladesh is very low as compare to those of some advanced tomato growing countries (Sharfuddin and Siddique, 1985). Tomato production in Bangladesh is affected by many factors, among them plant viruses such as Tomato Yellow Leaf Curl Virus (TYLCV) transmitted by whitefly (Bemisia tabaci) is one of the most important diseases of tomato causing heavy losses in yield and quality of fruits. It is one of the devastating diseases of the tomato crop and depending on the severity and stage of the infection causing heavy losses in yield. Yield loss exceeds $90 \%$, when infection occurred within four weeks after transplanting in the field (Saikia and Muniyappa, 1989). So, it is urgently needed to control whitefly for successful tomato production in our country.

Among the various control practices to suppress the prevalence of whitefly insecticides are the mostly used. Several crop protection chemicals belonging to organ chlorine, organophosphate and carbamate group have been used to control insect pests. However, the application of these insecticides left a film of persistent poison over the foliage and fruits (Dikshit et al., 2000) and insect developed resistance to these insecticides (Denholm et al., 1996). Therefore, there is a need to replace these conventional insecticides with newer molecules with a lesser dose of a few grams per hectare. Profenophos (organophosphate group), imidacloprid (neo nicotinyl group), cypermethrin (synthetic pyrethroid group), indoxacarb (oxadiazine group), profenophos + cypermethrin (mixture of organophosphate and synthetic parathyroid) are new molecules and reported to be effective and economical in controlling insect- pests in many vegetable crops. The organ chlorine and organ phosphorus compounds are considered as potential threat to all types of ecosystem. Different groups of insecticides have been recommended to control this white fly (Satpathy et al., 2004). To consider the negative effects of insecticides used in controlling the whitefly population less toxic and environmentally friendly techniques are need to be introduced.

In some previous study, evaluated that different type of mulches reduced the incidence of viral diseases and also found that mulching increased plant growth and yield. Mulching with aluminum color was found to be most effective in reducing number of whiteflies and delay the infection of TYLCV (Vani et al., 1989; Davino et al., 1996). In one previous study, it was investigated that insecticides (Carbofuran, Endosulfan, Dimethoate, Buprofezin and Triazophos) and cultural methods are most effective for the controlling of whitefly and TYLCV in tomatoes (Azam et al., 1997). Insecticide Imidacloprid used for indirectly controlling TYLCV through control of its vector whitefly (Ahmed et al., 2001). Botanicals, like several plant derived oils significantly reduced whitefly adults and immature for 5 days following application as compared to control (Butler et al., 1991). 
Chemical insecticides are most commonly used method in controlling whitefly, although they cause environmental pollution and are expensive, there for the development of alternative control strategies is urgently needed. The purpose of this study was to find out the suitable chemical that would be less toxic, botanicals or other management practice like mulching through this way it may be possible to control the insect vector, whitefly.

\section{MATERIALS AND METHODS}

\section{Identification of the disease and evaluating the efficacy of selected treatments}

Identification of the virus disease was done mainly through visual observation of typical symptoms of TYLCV infection like upward curling, cupping, with or without marginal chlorosis, smaller leaflets and stunting of the plant (Green and Kalloo, 1994; Sinistera et al., 2000). The incidence of TYLCV was calculated by counting the infected plants at 30, 45 and 60 DAT on the basis of the appearance of symptoms. To evaluate the efficacy of treatments in whitefly association, the data on the following parameters were taken: number of infected plants/plot, number of healthy leaves/plant, whitefly association, number of branches/plant, plant height $(\mathrm{cm})$, number of flowers/plant, number of fruits/plant, single fruit weight $(\mathrm{g})$, weight of fruits/plant $(\mathrm{kg})$ and fruit yield $\left(\mathrm{t} \mathrm{ha}{ }^{-1}\right)$. Chemical insecticides and other ingredients to prepare botanical insecticide were collected from market, silver metallic mulch was prepared by pasting aluminum foil paper on clear polythene paper.

\section{Preparation of Silver metallic plastic mulch and Neemax}

Clear polythene paper and aluminum foil paper were collected from the local market and then aluminum foil was pasted on polythene paper to prepare the silver metallic mulch. For preparation of Neemax (Neem leaves extract), collected neem leaves were weighted in an electric balance and then washed in the water. After washing the big leaves were cut into small pieces, blended in pastel and mortar and then distilled water was added into the mortar. The pulverized mass was squeezed through 3 folds of fine cotton cloth. For getting 1:2(w/v) ratio $200 \mathrm{ml}$ of distilled water was added with $100 \mathrm{~g}$ of blended leaves.

\section{Identification and estimation of disease incidence (\%) and disease severity (\%)}

Identification of the virus disease was done mainly through visual observation of typical symptoms of TYLCV infection like upward curling, cupping, with or without marginal chlorosis, smaller leaflets and stunting of the plant (Green and Kalloo 1994; Sinistera et al., 2000). The incidence of TYLCV was calculated by counting the infected plants 30, 45 and 60 DAT on the basis of the appearance of symptoms. The plants were inspected every morning to note the appearance of the symptoms starting from the following day of transplantation. 
The following formulas were used to calculate the percentage of disease incidence and severity:

Disease incidence $(\%)=\frac{X i}{X} \times 100$

$X_{i}=$ Number of infected plants in a unit plot

$\mathrm{X}=$ Total number of plant $\mathrm{s}$ in a unit

Disease severity $(\%)=\frac{A i}{A} \times 100$

$\mathrm{A}_{\mathrm{i}}=$ Number of infected leaves

$A=$ Total number of leaves in selected infected plant

\section{Evaluation of the efficacy of treatments in whitefly association}

The sampling of the study for whitefly association was taken from 30 DAT at vegetative stage, early flowering stage and early fruiting stage at 15 days interval. The plants were carefully checked visually for the presence of whitefly. Sometimes plants were shaken gently to observe their presence and count their number accurately. While the population of whitefly was very low, the number was recorded per 5 plants. Sampling on whitefly incidence was taken at both pre and post application of treatments. Two post treatment counts were taken at each vegetative, early flowering and early fruiting stages.

\section{Statistical analysis}

Data were analyzed by using computer-based software statistix-10 latest version. The means of growth and yield data were compared by DMRT, bar diagram and graphs were also used to interpret the data as and when necessary.

\section{RESULTS AND DISCUSSION}

\section{Effect of different treatments on disease incidence at 30, 45 and 60 DAT}

The disease incidence (\%) of TYLCV was ranged 1.65 to $9.98,1.27$ to 12.07 and 2.87 to 14.71 at 30,45 and $60 \mathrm{DAT}$, respectively. The lowest disease incidence $\left(1.65 \%\right.$ ) was found in $\mathrm{T}_{6}$ (Silver metallic plastic mulch) at $30 \mathrm{DAT}, 1.27 \%$ at 45 DAT and $2.87 \%$ at 60 DAT. Among chemicals, Imidacloprid significantly reduced disease incidence $2.99 \%, 2.72 \%$ and $6.41 \%$ at 30, 45 and 60 DAT, respectively, which was statistically similar with $\mathrm{T}_{2}$ (ACmix) and $\mathrm{T}_{3}$ (Submicron) and their disease incidence were $3.13 \%, 3.53 \%, 8.80 \%$ and $3.39 \%, 4.12 \%, 6.41 \%$, respectively. In case of botanical treatments, Multineem, $\mathrm{T}_{5}$ (Neem oil) showed moderate disease incidence which is statistically similar with Neemax, $\mathrm{T}_{4}$. These results are presented in Table 1. 
Table 1. Disease incidence (\%) of TYLCV under different treatments at 30, 45 and 60 DAT

\begin{tabular}{llll}
\hline Treatments & \multicolumn{3}{c}{ Disease incidence $(\%)$} \\
\cline { 2 - 4 } & $30 \mathrm{DAT}$ & $45 \mathrm{DAT}$ & $60 \mathrm{DAT}$ \\
\hline $\mathrm{T}_{1}$ (Imidacloprid) & $2.99^{\mathrm{c}}$ & $7.72^{\mathrm{e}}$ & $6.41^{\mathrm{d}}$ \\
$\mathrm{T}_{2}$ (ACmix) & $3.13^{\mathrm{c}}$ & $3.53^{\mathrm{d}}$ & $8.80^{\mathrm{c}}$ \\
$\mathrm{T}_{3}($ Subicron$)$ & $3.39^{\mathrm{c}}$ & $4.12^{\mathrm{c}}$ & $9.37^{\mathrm{c}}$ \\
$\mathrm{T}_{4}($ Neemax $)$ & $6.67^{\mathrm{b}}$ & $7.45^{\mathrm{b}}$ & $10.73^{\mathrm{b}}$ \\
$\mathrm{T}_{5}($ Multineem) & $5.30^{\mathrm{b}}$ & $6.93^{\mathrm{b}}$ & $9.59^{\mathrm{c}}$ \\
$\mathrm{T}_{6}($ Silver metallic plastic & $1.65^{\mathrm{d}}$ & $1.27^{\mathrm{f}}$ & $2.87^{\mathrm{e}}$ \\
mulch $)$ & $9.98^{\mathrm{a}}$ & $12.07^{\mathrm{a}}$ & $14.71^{\mathrm{a}}$ \\
$\mathrm{T}_{7}($ Control $)$ & 1.142 & 0.584 & 0.853 \\
$\mathrm{LSD}_{0.05}$ & 6.7553 & 6.753 & 8.271 \\
$\mathrm{CV}(\%)$ &
\end{tabular}

Means in the column having dissimilar letter (s) differ significantly at $5 \%$ level. $\mathrm{CV}=$ Coefficient of variation, $\mathrm{LSD}=$ Least significant difference.

\section{Effect of different treatments on disease severity (\%) at 30, 45 and 60 DAT}

The lowest disease severity was found in $\mathrm{T}_{6}$ (Silver Metallic Plastic Mulch) was $1.96 \%, 2.10 \%, 1.72 \%$ at 30, 45 and 60 DAT, respectively, whereas chemical and botanical treatments showed moderate to high disease severity ranged from 4.69 to $25.80 \%, 7.12$ to $27.43 \%$ and 15.08 to $46.22 \%$ at 30,45 and 60 DAT, respectively. Among chemicals, Imidacloprid showed best result, which was statistically similar with $\mathrm{T}_{2}$ (ACmix) and $\mathrm{T}_{3}$ (Subicron), whereas botanicals gave poor result in compare to other treatments. These results are presented in Table 2.

Table 2. Disease severity (\%) of TYLCV under different treatments at 30, 45 and 60 DAT

\begin{tabular}{llcc}
\hline Treatments & \multicolumn{3}{c}{ Disease Severity (\%) } \\
\cline { 2 - 4 } & 30 DAT & 45 DAT & 60 DAT \\
\hline $\mathrm{T}_{1}$ (Imidacloprid) & $4.69^{\mathrm{e}}$ & $7.12^{\mathrm{e}}$ & $15.08^{\mathrm{e}}$ \\
$\mathrm{T}_{2}$ (ACmix) & $7.53^{\mathrm{d}}$ & $11.26^{\mathrm{cd}}$ & $20.63^{\mathrm{d}}$ \\
$\mathrm{T}_{3}$ (Subicron) & $6.69^{\mathrm{d}}$ & $12.66^{\mathrm{c}}$ & $23.51^{\mathrm{c}}$ \\
$\mathrm{T}_{4}$ (Neemax) & $10.49^{\mathrm{b}}$ & $16.69^{\mathrm{b}}$ & $30.13^{\mathrm{b}}$ \\
$\mathrm{T}_{5}$ (Multineem) & $9.20^{\mathrm{bc}}$ & $13.25^{\mathrm{c}}$ & $24.47^{\mathrm{c}}$ \\
$\mathrm{T}_{6}$ (Silver metallic plastic mulch) & $1.96^{\mathrm{f}}$ & $2.10^{\mathrm{f}}$ & $1.72^{\mathrm{f}}$ \\
$\mathrm{T}_{7}($ Control) & $25.80^{\mathrm{a}}$ & $27.43^{\mathrm{a}}$ & $46.22^{\mathrm{a}}$ \\
$\mathrm{LSD}_{0.05}$ & 1.076 & 1.213 & 2.057 \\
$\mathrm{CV}(\%)$ & 6.274 & 8.152 & 8.875 \\
\hline
\end{tabular}

Means in the column having dissimilar letter (s) differ significantly at $5 \%$ level.

$\mathrm{CV}=$ Coefficient of variation, $\mathrm{LSD}=$ Least significant difference. 


\section{Effect of different treatments on whitefly association at 30, 45 and 60 DAT in pre and post treatment}

In terms of whitefly association, significant variation was observed among the performance of treatments against whitefly. It was observed that the lowest whitefly association (2.0, 4.0 and 2.0 at 30, 45 and 60 DAT, respectively) was found in $\mathrm{T}_{6}$ (Silver Metallic Plastic mulch) followed by $\mathrm{T}_{1}$ (Imidacloprid), $\mathrm{T}_{2}$ (ACmix) and $\mathrm{T}_{3}$ (Subicron) treatments. The highest whitefly association (19,23 and 18 at 30, 45 and 60 DAT, respectively) was recorded in Control treatment $\left(\mathrm{T}_{7}\right)$ during crop duration. Among the treated plants the moderate whitefly association (14, 14 and 12 at 30, 45 and 60 DAT respectively) was observed in $\mathrm{T}_{4}$ (Neemax), which was statistically identical with $\mathrm{T}_{5}$ (Multineem) at different observation. The results of the present study demonstrated that $\mathrm{T}_{6}$ (Silver metallic plastic mulch), $\mathrm{T}_{1}$ (Imidacloprid) and $\mathrm{T}_{2}$ (ACmix) treatment were as the best to control whitefly association (Figure 1).

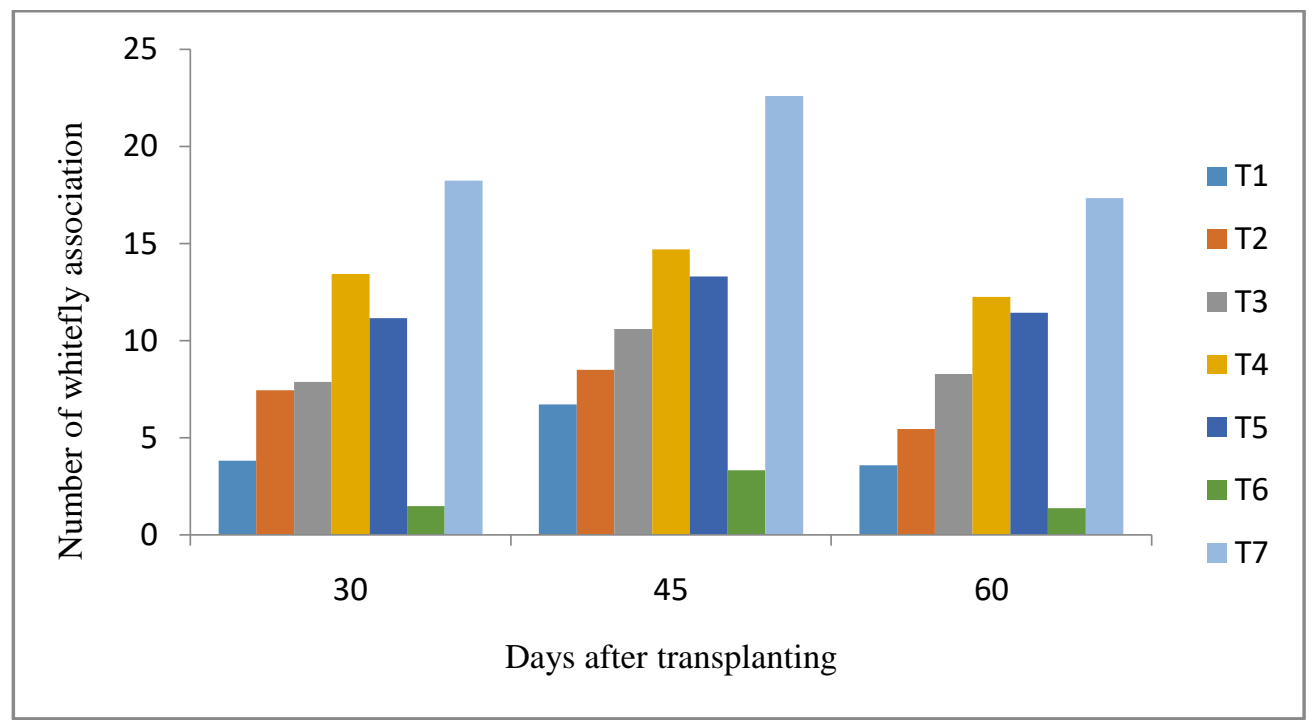

Figure 1. Whitefly association at 30, 45 and 60 DAT under different treatment relationship between disease incidence, severity and whitefly association

From the Figure 2, it revealed that \% disease incidence was increased with the increased of whitefly association. The highest $(14.71 \%)$ disease incidence was recorded in $\mathrm{T}_{7}$ (control) and whitefly association (18) were recorded in $\mathrm{T}_{7}$. The lowest number (2.0) of whitefly were recorded in the $\mathrm{T}_{6}$ (mulch treatment) and disease incidence was $1.72 \%$. From the Figure 3, it revealed that \% disease severity was increased with the increased of whitefly association. The highest disease severity (46.22 \%) was recorded in $\mathrm{T}_{7}$ (control) and whitefly association (18) were recorded in $\mathrm{T}_{7}$. The lowest number of whitefly (2.0) were recorded in the $\mathrm{T}_{6}$ (mulch treatment) and disease severity was $2.87 \%$. 


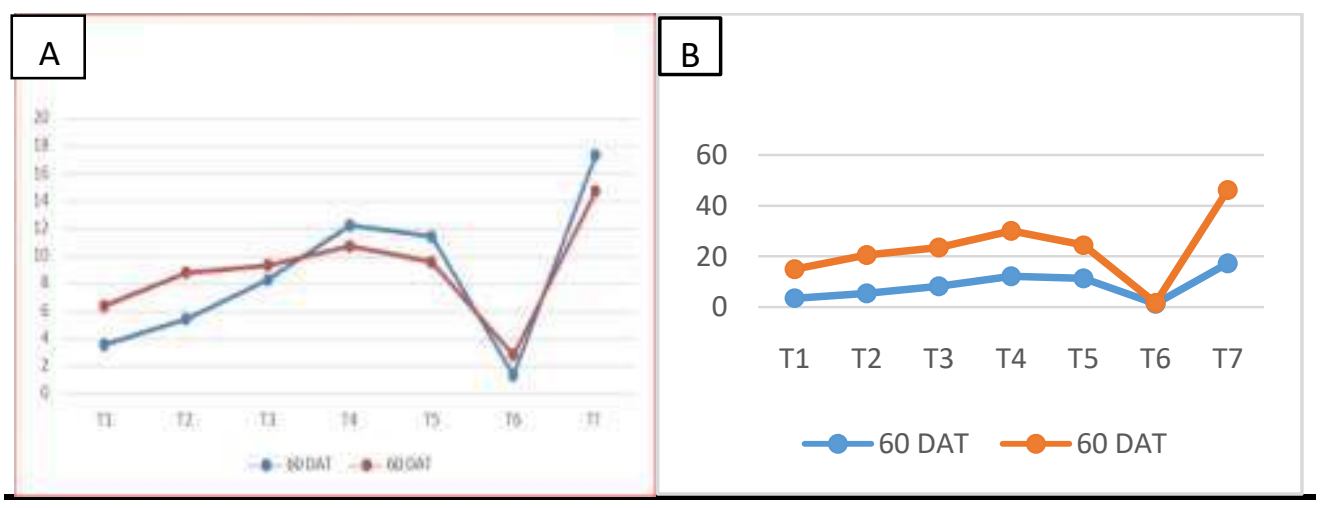

Figure 2.A. Relationship between disease incidence and whitefly association.

B. Relationship between disease severity and whitefly association.

The morphological feature which are identical, in relation to growth promoting characters in tomato against Tomato Yellow Leaf Curl Virus (TYLCV)

\section{Plant height (cm)}

The results on the effect of TYLCV infection on plant height of tomato under different treatments are summarized in (Table 3). Significant variation was found on plant height among the treatments. Irrespective of treatments healthy plants produced higher plant height in comparison to TYLCV infected plants. The $\mathrm{T}_{6}$ (Silver Metallic Plastic mulch) treatment produced the highest plant height $99.21 \mathrm{~cm}$ at followed by $\mathrm{T}_{1}$ (Imidacloprid), $94.25 \mathrm{~cm}$ and $\mathrm{T}_{2}$ (ACmix), $91.39 \mathrm{~cm}$. Lowest plant height $79.99 \mathrm{~cm}$ was achieved from Control treatment $\left(\mathrm{T}_{7}\right)$. Among the treated plants, the lowest plant height was achieved from $\mathrm{T}_{5}$ (Multineem), $85.75 \mathrm{~cm}$ followed by $\mathrm{T}_{4}$ (Neemax), $83.83 \mathrm{~cm}$.

Table 3. Effect on plant height of Tomato Yellow Leaf Curl Virus under different treatments

\begin{tabular}{lcl}
\hline Treatments & Plant height $(\mathrm{cm})$ & $\begin{array}{l}\text { Plant height increased } \\
\text { over control }\end{array}$ \\
\hline $\mathrm{T}_{1}$ (Imidacloprid) & $94.25^{\mathrm{b}}$ & $14.26^{\mathrm{b}}$ \\
$\mathrm{T}_{2}$ (ACmix) & $91.39^{\mathrm{c}}$ & $11.4^{\mathrm{c}}$ \\
$\mathrm{T}_{3}$ (Subicron) & $87.37^{\mathrm{d}}$ & $7.38^{\mathrm{d}}$ \\
$\mathrm{T}_{4}$ (Neemax) & $83.83^{\mathrm{e}}$ & $3.84^{\mathrm{e}}$ \\
$\mathrm{T}_{5}$ (Multineem) & $85.75^{\mathrm{f}}$ & $5.76^{\mathrm{f}}$ \\
$\mathrm{T}_{6}$ (Silver metallic plastic mulch) & $99.21^{\mathrm{a}}$ & $19.22^{\mathrm{a}}$ \\
$\mathrm{T}_{7}($ Control) & $79.99^{\mathrm{g}}$ & --- \\
$\mathrm{LSD}_{0.05}$ & 1.36 & --- \\
$\mathrm{CV}(\%)$ & 10.64 & --- \\
\hline
\end{tabular}

Means in the column having dissimilar letter (s) differ significantly at $5 \%$ level.

$\mathrm{CV}=$ Coefficient of variation, $\mathrm{LSD}=$ Least significant difference. 
The morphological features which are identical, in relation to yield and yield contributing parameters in tomato against Tomato Yellow Leaf Curl Virus

Number of flowers/plants, fruits/plant, weight of fruits/plant, single fruit weight, fruit yield

Number of flowers/plants was significantly affected by TYLCV under different treatments (Table 4). Among the different treatments, $\mathrm{T}_{6}$ (Silver mulch) performed best for number of flowers/plants 34.60, which was significantly different from all other treatments. It was also found that the treatment Control treatment $\left(\mathrm{T}_{7}\right)$ showed lowest number of flowers/plant 21.36. Among the treated plants, the lowest number of flowers/plant was achieved from $\mathrm{T}_{4}$ (Neemax), 23.22 which was statistically identical with $\mathrm{T}_{5}$ (Multineem), 24.73. Number of fruits/plant was significantly influenced by TYLCV performed against different treatments applied to the crop to control whitefly (Table 4). Results indicated that the treatment, $\mathrm{T}_{6}$ (Silver Metallic Plastic mulch) produced highest number of fruits/plant (31.84) which was significantly different from all other treatments. Among the treated plants, the lowest number of fruits/plants was found from $\mathrm{T}_{4}$ (Neemax), 20.93. The highest weight of fruits/plant $\left(3.08 \mathrm{~kg}\right.$ ) was found from the treatment, $\mathrm{T}_{6}$ (Silver mulch) which was significantly different from all other treatments. The lowest weight of fruits/plant $(1.24 \mathrm{~kg})$ was produced from the control treatment $\left(\mathrm{T}_{7}\right)$, which was also significantly different from all other treatments. Among the treated plants, the lowest weight of fruits/plant was found from $\mathrm{T}_{4}$ (Neemax). The TYLCV transmitted by whitefly had significant influence on single fruitweight of tomato against different treatments applied (Table 4). The treatment, $\mathrm{T}_{6}$ (Silver mulch) produced highest single fruit weight $(95.68 \mathrm{~g})$ followed by $\mathrm{T}_{1}$ (Imidacloprid), which was significantly different from all other treatments. Among the treated plants, the lowest single fruit weight $(90.25 \mathrm{~g})$ was found from $\mathrm{T}_{4}$ (Neemax), which was statistically identical with $\mathrm{T}_{3}$ (Subicron). Fruit yield/ha performed best $\left(53.35 \mathrm{tha}^{-1}\right)$ from the treatment, $\mathrm{T}_{6}$ (Silver Metallic Plastic mulch) against TYLCV and found signification variation among all the treatments. The second highest and third highest fruit yield (47.49 and 44.51 $\mathrm{t} \mathrm{ha}^{-1}$, respectively) was achieved from $\mathrm{T}_{1}$ (Imidacloprid) and $\mathrm{T}_{2}$ (ACmix), respectively. Among the treated plants, the lowest fruit yield $\left(10.15 \mathrm{tha}^{-1}\right)$ was found from $\mathrm{T}_{4}$ (Neemax) which was statistically identical $\mathrm{T}_{5}$ (Multineem). 
Table 4. Effect on yield and yield contributing parameters of tomato through management of tomato yellow leaf curl virus using different treatments

\begin{tabular}{lccccc}
\hline & \multicolumn{5}{c}{ Yield and yield contributing parameters } \\
\cline { 2 - 6 } Treatments & $\begin{array}{c}\text { Number } \\
\text { of } \\
\text { flowers/ } \\
\text { plant }\end{array}$ & $\begin{array}{c}\text { Number } \\
\text { of } \\
\text { fruits/ } \\
\text { plant }\end{array}$ & $\begin{array}{c}\text { Weight of } \\
\text { fruits/ } \\
\text { plant }(\mathrm{kg})\end{array}$ & $\begin{array}{c}\text { Single } \\
\text { fruit } \\
\text { weight } \\
(\mathrm{g})\end{array}$ & $\begin{array}{c}\text { Average } \\
\text { fruit } \\
\text { diameter } \\
(\mathrm{cm})\end{array}$ \\
\cline { 2 - 7 } $\mathrm{T}_{1}$ (Imidacloprid) & $32.12^{\mathrm{b}}$ & $29.39^{\mathrm{b}}$ & $2.74^{\mathrm{b}}$ & $93.17^{\mathrm{b}}$ & $13.67^{\mathrm{b}}$ \\
$\mathrm{T}_{2}$ (ACmix) & $30.63^{\mathrm{b}}$ & $28.10^{\mathrm{c}}$ & $2.57^{\mathrm{c}}$ & $91.57^{\mathrm{c}}$ & $12.91^{\mathrm{c}}$ \\
$\mathrm{T}_{3}$ (Subicron) & $27.24^{\mathrm{c}}$ & $25.80^{\mathrm{d}}$ & $2.34^{\mathrm{d}}$ & $90.52^{\mathrm{d}}$ & $11.47^{\mathrm{d}}$ \\
$\mathrm{T}_{4}($ Neemax) & $23.22^{\mathrm{d}}$ & $20.93^{\mathrm{f}}$ & $1.89^{\mathrm{f}}$ & $90.25^{\mathrm{d}}$ & $10.15^{\mathrm{e}}$ \\
$\mathrm{T}_{5}$ (Multineem) & $24.73^{\mathrm{d}}$ & $22.26^{\mathrm{e}}$ & $2.03^{\mathrm{e}}$ & $91.43^{\mathrm{c}}$ & $10.49^{\mathrm{e}}$ \\
$\mathrm{T}_{6}($ Silver metallic plastic & $34.60^{\mathrm{a}}$ & $31.84^{\mathrm{a}}$ & $3.08^{\mathrm{a}}$ & $95.68^{\mathrm{a}}$ & $14.57^{\mathrm{a}}$ \\
mulch) & & & & & \\
$\mathrm{T}_{7}($ Control) & $21.36^{\mathrm{e}}$ & $16.08^{\mathrm{g}}$ & $1.24^{\mathrm{g}}$ & $76.75^{\mathrm{e}}$ & $8.04^{\mathrm{f}}$ \\
$\mathrm{LSD}_{0.05}$ & 1.617 & 0.614 & 0.116 & 0.327 & 0.415 \\
$\mathrm{CV}(\%)$ & 8.636 & 6.421 & 4.713 & 8.334 & 6.528 \\
\hline
\end{tabular}

Means in the column having dissimilar letter (s) differ significantly at 5\% level. $\mathrm{CV}=$ Coefficient of variation, $\mathrm{LSD}=$ Least significant difference.

\section{CONCLUSION}

Among the set treatments, Silver mulch $\left(\mathrm{T}_{6}\right)$ performed the best among all other treatments to manage $T Y L C V$ by controlling whitefly and gave the best results regarding growth promoting characters, yield and yield attributes. Among the treated plants, the results on different parameters, achieved lower performance from botanical treatments, Neemax $\left(\mathrm{T}_{4}\right)$ and Multi Neem $\left(\mathrm{T}_{5}\right)$ in most of the cases where the Imidacloprid (treatment $T_{1}$ ) showed comparatively better performance next to treatment Silver mulch $\left(\mathrm{T}_{6}\right)$. From the above findings on different parameters studied, it can be concluded that the treatment Silver colored mulch was best against whitefly association in test crop tomato against TYLCV for tomato cultivation compared to other considering treatments including control treatment.

\section{ACKNOWLEDGMENT}

Technical assistance from members of Molecular Plant Virology Laboratory, Department of Plant Pathology and all work forces of Sher-e-Bangla Agricultural University, Dhaka-1207, Bangladesh, was greatly appreciated. 


\section{REFERENCES}

Ahmed, N.E., Kanan, H.O., Sugimoto, Y., Ma, Y.O. and Inanaga, S. (2001). Effect of imidacloprid on incidence of tomato yellow leaf curl virus. Plant Disease, 85(1):84-87.

Azam, K.M., Razvi, S.A., Ali, Z. and Rauesi, A.A. (1997). Management of whitefly (Bemisia tabaci Gennadius) and tomato leaf curl virus in tomato crops. Indian Journal of Plant Protection, 25:36-41.

Butler, G.D.Jr. and Henneberry, T.J. (1991). Sweet potato whitefly control: Effect of tomato cultivars and plant derived oils. Southwestern Entomologist, 16(1): $37-43$.

Davino, M., D’Urso, F., Areddia, R., Carbone, M. and Mauromicale, G. (1994). Investigation on the epidemiology of Tomato yellow leaf curl virus (TYLCV) in sicily. Petria, 4:151-160.

Dikshit, A.K., Lal, O.P. and Shrivastava, Y.N. (2000). Persistence of parathyroid and nicotinyl insecticides on okra fruits. Pesticides Research Journal, 12(2):227-231.

Divakaran, A. (2007). Molecular characterization of tomato with special reference to ToLCV resistance. MSc (Ag) thesis, Kerala Agricultural University, Vellanikkara, Thrissur. Pp. 71.

Green, S.K. and Kalloo, C. (1994). Leaf curl and yellowing disease of tomato. In: Technical Bulletin No.21. Leaf curl and yellowing viruses of pepper and tomato. In an overview Asian Vegetable Research and Development Centre. Pp. 21-51.

Satpathy, S., Rai, S., De, N. and Singh, A.P. (2004). Effect of insecticides on leaf net carbon assimilation rate and pest incidence in okra. Indian Journal of Plant Protection, 32:22-25.

Sharfudin, A.F.M. and Siddique, M.A. (1985). SabjiBigyan. $1^{\text {st Edition, Bangladesh }}$ Agricultural University, Mymensingh. Pp. 4.

Saikia, A.K. and Muniyappa, V. (1989). Epidemiology and control of tomato leaf curl virus in southern India. Tropical Agriculture, 66(4):350-354.

Vani, S., Varma, A., Mora, T.A., and Srivastava, K.P. (1989). Use of mulches for the management of mosaic diseases in muskmelon. Indian Phytopathology, 42(2):227-235.

Sinistera, X., Patte, C.P., Siewnath, S. and Polston, J.E. (2000). Identification of tomato yellow leaf curl virus-Is in the Bahamas. Plant Disease, 84(5):592. 